\title{
A Case of Chronic Eosinophilic Pneumonia Confused with Covid-19 Pneumonia
}

\author{
Covid-19 Pnömonisi ile Karışan Kronik Eozinofilik Pnömoni Olgusu
}

Selvi Aşker', Hanifi Yıldız', Nevzat Esen', Müntecep Aşker²

\section{Abstract}

The etiology of chronic eosinophilic pneumonia (CEP) is not precisely known, although its characteristic features include eosinophilia, involving alveoli or blood; subacute or chronic respiratory and general symptoms; while chest radiological imaging shows peripheral pulmonary infiltrates. Many cases of pneumonia associated with the new coronavirus (2019-nCoV) were detected in Wuhan, China starting in December 2019. HRCT is a highly sensitive and convenient screening tool for 2019-nCoV. The radiological appearance of the new coronavirus pneumonia is not very different from that of the common viral pneumonia, but it has some unique features. It usually manifests with patchy or punctuate opacities resembling ground glass (85.7\%), and patchy consolidation (19.0\%), and the lesions are mainly located in the subpleural area. Here we present a case of CEP who presented with shortness of breath, cough, fever, and a clinical and radiological picture similar to COVID-19.

Key words: Chronic eosinophilic pneumonia (CEP), SARS-CoV-2, Computed Tomography, Ground Glass Opacity.

\section{Özet}

Kronik eozinofilik pnömoninin (KEP) etiyolojisi tam olarak bilinmemektedir. KEPi, alveollerde ya da kanda eozinofili ile seyreden,subakut veya kronik solunumsal ya da genel semptomları olan ve akciğer radyolojisinde periferik tutulumla karekterize bir hastalıktır. Yeni koronavirüs (2019-nCoV) ile enfekte olmuş birçok pnömoni olgusu, Aralık 2019'dan beri Çin'in Wuhan şehrinde tespit edildi. HRCT, 2019 nCoV için çok hassas ve kullanışlı bir tarama aracıdır. Yeni koronavirüs pnömonisinin radyolojik görünümü kendine has özellikleri olmakla birlikte yaygın viral pnömoniden çok farklı değildir. Genellikle buzlu cam (\% 85.7) ve düzensiz konsolidasyona (\% 19.0) benzeyen yamalı ya da bölgesel opasiteler ile kendini gösterir. Lezyonlar esas olarak subplevral bölgede bulunur. Burada nefes darlığı, öksürük, ateş ve COVID19 'a benzer klinik ve radyolojik tablo ile başvuran bir KEP olgusu sunulmaktadır.

Anahtar Sözcükler: Kronik eozinofilik pnömoni (CEP), SARS-CoV-2, Bilgisayarlı Tomografi, Buzlu Cam Opasitesi.

\footnotetext{
'Department of Chest Disease, Van Yüzüncü Yıl University Medical Faculty, Van, Turkey

2Department of Cardiology, Van Yüzüncü Yıl University Medical Faculty, Van, Turkey

'Yüzüncü Yıl Üniversitesi Tıp Fakültesi, Göğüs Hastalıkları Anabilim Dalı, Van

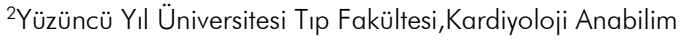
Dalı, Van
}

Submitted (Başvuru tarihi): 23.06.2020 Accepted (Kabul tarihi): 21.10.2020

Correspondence (iletişim): Selvi Aşker, Department of Chest Disease, Van Yüzüncü Yıl University Medical Faculty, Van, Turkey

e-mail: selviasker@gmail.com 
Chronic eosinophilic pneumonia (CEP) is a rare disorder, the etiology of which is not exactly known. Its characteristic features are eosinophilia involving alveoli or blood; subacute or chronic respiratory and general symptoms; and a chest radiological imaging with peripheral pulmonary infiltrates (1). Females are affected by CEP twice as often as males, and it is commonly seen in asthmatic patients (2).

A history of asthma is seen in two-thirds of patients, and nearly half of the patients have a history of atopia, ranging from eczema and nasal polyposis to urticaria (3). The symptoms begin silently, and the most frequent are cough, dyspnea, fatigue, weight loss and fever. There are no clear-cut diagnostic criteria for CEP, although eosinophilia of the peripheral blood is usually present. In bronchoalveolar lavage (BAL), the percentage of eosinophils is elevated, in the $12-95 \%$ range, with a mean of $58 \%$ (3). There may also be increases in lgE levels, erythrocyte sedimentation rate and $\mathrm{C}$-reactive protein. Chest-X-rays of the original CEP series revealed peripheral opacities that resembled "photographic negatives" of pulmonary edema. Although there may be varying patterns, peripherally distributed patchy airspace consolidations may be seen in computed tomographies (CT) of the chest (2).

Alveolar infiltrates are bilateral in $97 \%$ of cases, but can also be unilateral (3). Such opacities are usually found at the periphery of the upper lobes, and the appearance may be ground glass or consolidation. The higher sensitivity of CT better reveals pulmonary features and more accurately defines CEP. Both pleural effusions and radiographic cavitations are rare manifestations of CEP (2).

Prior to making a CEP diagnosis, eosinophilia due to infections, toxic etiologies or drugs should be excluded. Treatment mainly involves corticosteroids, and treatment response is rapid. Despite corticosteroid treatment, the asthma accompanying CEP may be progressive and often severe (3). Many patients have good long-term prognosis, but relapses may occur, especially during the tapering process of oral corticosteroid therapy. Up to half of the patients may relapse, and some patients may experience multiple recurrences.

Table 1: Similar and Different Radiologic Features of CEP and COVID-19 pneumonia

\begin{tabular}{|c|c|}
\hline COVID-19 & Chronic Eosinophilic Pneumonia \\
\hline $\begin{array}{l}\text { Multifocal and particularly the lower lobes distrubution, subpleural } \\
\text { and peripheral patchy ground glass opacities }\end{array}$ & $\begin{array}{l}\text { Non-segmental, Migratory peripheral airspace } \\
\text { ground-glass opacities, mainly the upper lobes }\end{array}$ \\
\hline $\begin{array}{l}\text { Intralobular and interlobuler reticulations, resulting in a crazy paving } \\
\text { pattern }\end{array}$ & $\begin{array}{l}\text { Longitudinal bands coursing vertically parallel to the } \\
\text { pleural surface }\end{array}$ \\
\hline Reversed halo sign & - \\
\hline Alveolar consolidation & $\begin{array}{l}\text { Consolidation with peripheral lung distribution, pho- } \\
\text { tograph negative appearance of pulmonary edema }\end{array}$ \\
\hline Widespread ground glass opacities with ARDS & - \\
\hline Endobronchial mucoid impaction & Endobronchial mucoid impaction \\
\hline $\begin{array}{l}\text { Centrilobular pulmonary nodules may be present, sometimes with a } \\
\text { tree-in-bud pattern reflecting small airways involvement }\end{array}$ & $\begin{array}{c}\text { Centrilobular pulmonary nodules may be present, } \\
\text { sometimes with a tree-in-bud pattern reflecting small } \\
\text { airways involvement }\end{array}$ \\
\hline Pleural effusions and cavitation are rare & Pleural effusions and cavitation are rare \\
\hline
\end{tabular}


Many cases of pneumonia associated with the new coronavirus (2019-nCoV) were detected in Wuhan, China starting in December 2019, and the disease then spread rapidly around the world (4). High-resolution computed tomography (HRCT) of the chest is a highly sensitive and feasible screening tool for 2019-nCoV (5). Although the radiological appearance of COVID-19 pneumonia resembles common viral pneumonia, it has also some unique characteristics, such as patchy ground-glass opacities (85.7\%) and patchy consolidations (19.0\%), which are mostly seen in sub-pleural locations (4). For the diagnosis of COVID-19, a chest CT has high sensitivity (Table 1). In epidemic areas where the pre-test probability of the disease is high, a chest CT may be used for the screening, evaluation and follow up of COVID-19. Positive CT findings still suggest COVID-19 in epidemic areas, even if a RT-PCR is negative (5). The CT findings in COVID-19 coincide with other pulmonary diseases. Bronchoalveolar lavage $(\mathrm{BAL})$ is used for the diagnosis and follows up of many pulmonary diseases, and is carried out to identify cellular characteristics in interstitial lung diseases, and to define the etiological agent in patients in whom diagnosis and treatment could not be made. In patients with strong suspicions of Coronavirus, BAL may identify the agent when it cannot be isolated by any other means. IDSA recommends performing lower respiratory tract sampling in patients whose initial upper respiratory tract samples are negative (6). In viral infections, lymphocytes are expected to dominate in the early days of infection when bacterial infections are not accompanying. However, cellular features may change later due to superinfections or cytokine storm, and BAL findings may also change (7). We present here a case whose radiological imaging suggested COVID-19 pneumonia, although the subsequent diagnosis was CEP.

\section{CASE}

A 24-year old female patient was admitted to the COVID-19 clinic with shortness of breath, cough and fatigue. She had no overseas travel history, although her contact history was suspicious. The patient, who had a previous asthma diagnosis, had a fever of $37.5^{\circ} \mathrm{C}$; systol- ic blood pressure of $110 \mathrm{mmHg}$; and diastolic blood pressure of $60 \mathrm{mmHg}$. The pulse rate was 88 beats/min, and the respiration rate was 24 . Breathing sounds were normal. A chest $X$-ray revealed a suspicious infiltration in all zones of both lungs, with prominent air-filled areas at the periphery. CT showed ground-glass densities, most prominently in the upper regions of both lungs, adjacent to the pleura (Figure 1).

Nasopharyngeal and oropharyngeal swabs were obtained for COVID-19 assessment, and the patient was hospitalized in a ward accepting suspicious COVID-19 patients. Her blood count is presented in Table 2. Her hospital records revealed high eosinophil numbers at the time of previous assessments. A CT record was found from 2016 and compared, and the lesions seen in 2020 were more intense (Figure 2). A tuberculin skin test was negative; and serological tests were negative for Mycoplasma pneumonia, Chlamydia pneumonia, Adenovirus, Legionella, Aspergillus, Cryptosporidium and Candida. Both serological tests and stool exams were negative for parasites, and there were negative results for antinuclear antibodies, anti-double-stranded DNA, anti-mitochondria, anti-LKM antibodies, c-ANCA and p-ANCA, ruling out autoimmune diseases. There are various known causes of eosinophilic lung disease (ELD), including allergic bronchopulmonary aspergillosis, drug reactions, parasitic infections and eosinophilic vasculitis (Churg-Strauss syndrome). Allergic bronchopulmonary aspergillosis, parasitic infections and drug-induced eosinophilic pneumonia (EP) were excluded; and the absence of cutaneous vasculitis or other multiorgan involvements ruled out ChurgStrauss syndrome. Echocardiography revealed no cardiac pathology. A previous bronchoalveolar lavage, the eosinophils percentage was $25 \%$ (Table 3 ). Steroid treatment was initiated at the center at which the tests were performed, but the patient terminated treatment voluntarily, and did not attend any follow up visits. The patient was taking salmeterol, fluticasone propionate, and montelukast regularly. COVID-19 PCR tests were performed twice, and both were negative. Upon the diagnosis of CEP, prednisolone $1 \mathrm{mg} / \mathrm{kg}$ was initiated, and the patient was discharged. 
Table 2: Laboratory data of the patient (2020)

\begin{tabular}{|c|c|c|}
\hline Variable & Reference Range & On Arrival, Emergency Department \\
\hline Hematocrit (\%) & $41.0-53.0$ & 42,1 \\
\hline Hemoglobin (g/dl) & $13.5-17.5$ & 13,6 \\
\hline White-cell count (per $\mu$ l) & $4500-11,000$ & 11,600 \\
\hline Neutrophils (\%) & $28-78$ & 62,8 \\
\hline Lymphocytes (\%) & $17-57$ & 19,7 \\
\hline Eosinophil (\%) & $0-10$ & 13,3 \\
\hline Platelet count (per $\mu$ l) & $130,000-400,000$ & 313,000 \\
\hline Carbon dioxide (mmol/l) & 23-38 & 36,8 \\
\hline Creatinine $(\mathrm{mg} / \mathrm{dl})$ & $0.60-1.50$ & 0,55 \\
\hline Glucose (mg/dl) & $70-110$ & 78 \\
\hline Alanine aminotransferase (U/liter) & $10-55$ & 22 \\
\hline Aspartate aminotransferase (U/liter) & $10-40$ & 38 \\
\hline C-reactive protein (mg/liter) & $8-25$ & 13,6 \\
\hline Lactate dehydrogenase $\mu /$ liter & $125-220$ & 138 \\
\hline Sedimentation & $1-20$ & 23 \\
\hline D-Dimer & $0-0,5$ & 0,43 \\
\hline Total lgE (IU/ml) & $0-100$ & 71,5 \\
\hline
\end{tabular}

Table 3: Bronchoalveolar lavage results

\begin{tabular}{|c|c|c|}
\hline Variable & Reference Range & On Arrival, chest disease Department \\
\hline Neutrophils (\%) & $50-80$ & 44 \\
\hline Eosinophil (\%) & $0-5$ & 25 \\
\hline Lymphocytes (\%) & $25-50$ & 23,7 \\
\hline CD4(\%) & $34-56$ & 13,4 \\
\hline CD8(\%) & $18-36$ & Negative \\
\hline Tuberculosis culture & & Negative \\
\hline Covid -19 RT(PCR) & & Negative \\
\hline PCP culture & & Inflammation rich from eosinophilic leukocytes \\
\hline
\end{tabular}



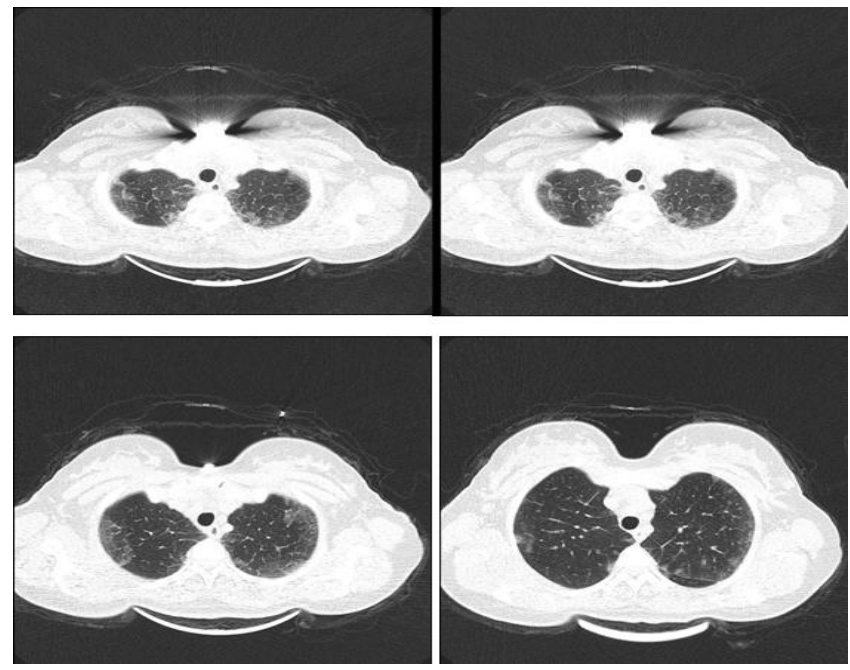

Figure 1: Axial CT image of the patient from 2020, showing bilateral pleural-based ground glass and consolidation areas. A CT axial view of the patient showing the bilateral pleural-based ground-glass appearance and consolidation areas
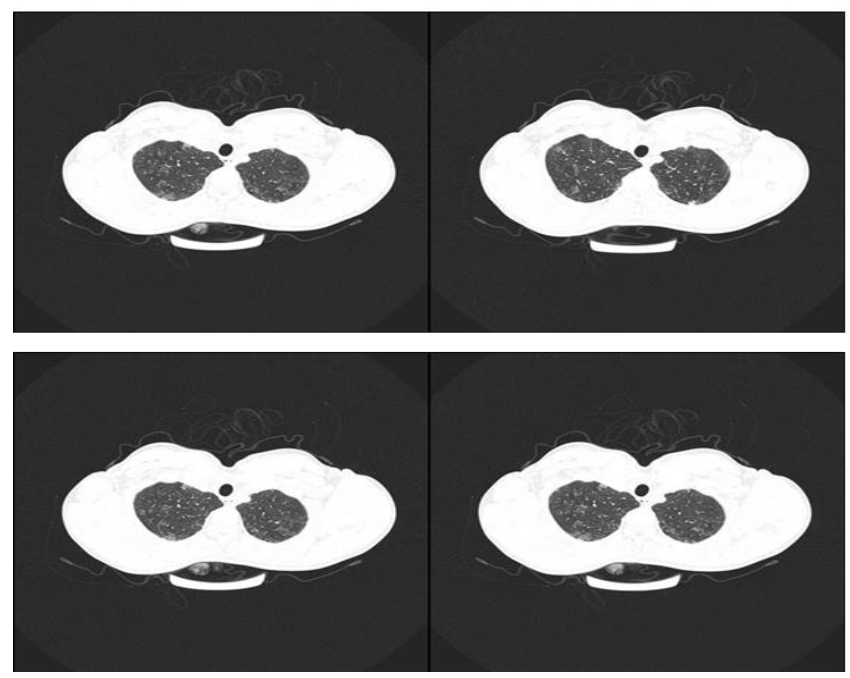

Figure 2: A CT axial image of the patient from 2016 showing bilateral pleural-based ground-glass appearance and consolidation areas

\section{DISCUSSION}

CEP, first described by Carrington et al. (8) in 1969, is a rare disorder children aged 2-5 years, although the actual incidence and prevalence are unknown. In the adult population, women are more frequently affected than men. Onset is insidious with non-specific general symptoms, including cough, dyspnea, night sweats, weight loss, fever, wheezing and sputum production, although these symptoms may easily be misdiagnosed as an infectious illness, contributing to a delay in diagnosis and treatment (8). Chronic eosinophilic pneumonia can be differentiated from acute eosinophilic pneumonia based on the prolonged symptom duration, history of asthma, the occurrence of relapse and radiologic features of subpleural consolidation (9). Chronic eosinophilic pneumonia (CEP) is a rare disorder that responds well to corticosteroids, although there is a lack of consensus on the initial dose and treatment duration with corticosteroids. The most significant complication is recurrence, which develops during the tapering process. The patient in the present study experienced recurrence after terminating her treatment. It is likely that the intermittent use of steroids for the treatment of her asthma prevented relapse, although as the recurrence amid the COVID pandemic, led to diagnostic confusion due to the similarities in radiological involvement.

The new coronavirus, which first appeared in Wuhan, China, has been named officially COVID-19 by WHO. The disease was initially local, but then spread around the entire world (4). It is hard to differentiate between the radiological features of COVID-19 pneumonia and those of common viral pneumonia, although there are some specific imaging features. Patchy or punctate opacity resembling ground glass (GGO) is the most frequent radiologic presentation, although there may also be a patchy consolidation (4). The findings of a previous study have emphasized the use of chest CT for diagnoses of COVID-19 in patients with negative RT-PCR test results, as chest imaging may play a key role in diagnosis when RT-PCR gives negative results at an early stage. For rapid diagnosis, changes in radiological appearance should be clearly identified. CT findings alone are usually not enough to differentiate COVID-19 from other viral pneumonias, although a high-resolution CT (HRCT) of the chest may be used when RT-PCR yields negative results (10). Radiologists will encounter more patients as the number of 2019-nCoV cases increases. A detailed travel and exposure history should be obtained before considering the disease, and radiologists should suspect 2019 $\mathrm{nCoV}$ in patients with bilateral ground-glass opacities or consolidation. RT-PCR for 2019-nCoV may yield negative results for some patients with positive chest CT findings (11). Previous studies have found that CT images in the majority of cases showed GGO or mixed GGO and consolidation. Pneumonia due to $2019-n C o V$ is likely to present with a peripheral distribution, and to involve the lower lungs bilaterally (12). As a non-invasive imaging modality, chest CT offers high accuracy and speed. Recent studies have reported characteristic CT findings such GGOs with or without crazy-paving sign, multifocal organizing pneumonia and peripheral architectural distortions. In the present study, $60 \%$ of patients had typical CT features at the time of, or prior to, the initial positive RTPCR results (13). Furthermore, in almost all patients, a chest $C T$ yielded positive results before or within six days 
of the initial positive RT-PCR results. These results suggest that $C T$ imaging may be very useful for detecting cases of suspected COVID (5). The rate of confirmed RT-PCR assays in the present study (97\%) was higher than in a previous study conducted by Kanne et al. (76.4\%) (11). The first study, which demonstrated higher rates for the concordance of CT imaging, was conducted in the largest hospital in Wuhan, China. As this city was the center of the COVID-19 outbreak, radiologists may have had a high index of suspicion, and may have more readily diagnosed COVID-19 when encountering typical CT features. These results suggest that the sensitivity of chest $\mathrm{CT}$ for COVID-19 is high, and that chest CT may be used for screening, comprehensive evaluation and follow up purposes COVID-19 outbreak areas, and where the pre-test probability of the disease is high (5). In another trial, the clinical features and chest CT characteristics of six patients were evaluated, and a decreased eosinophil count was found to be helpful in the diagnosis of the disease in an early period. The study also identified a variety of new CT manifestations on CT. Lesions may appear as round nodular-like GGOs in the central region of the lung lobe, different to the patch-like lesions in the subpleural area noted in many previous trials (14).

In conclusion, computed tomography is used as routinely in the current COVID-19 pandemic, and some physicians regarded all patients as if COVID-19 pneumonia. This situation caused cases whose tomographic appearance was confused with COVID-19 pneumonia. A detailed anamnesis, previous radiological images, and clinical, biochemical and microbiological data should be evaluated together for an accurate diagnosis.

\section{CONFLICTS OF INTEREST}

None declared.

\section{AUTHOR CONTRIBUTIONS}

Concept - S.A., H.Y., N.E., M.A.; Planning and Design S.A., H.Y., N.E., M.A.; Supervision - S.A., H.Y., N.E., M.A.; Funding - S.A.; Materials - S.A.; Data Collection and/or Processing - S.A.; Analysis and/or Interpretation S.A.; Literature Review - S.A.; Writing - S.A.; Critical Review - S.A.

\section{YAZAR KATKILARI}

Fikir - S.A., H.Y., N.E., M.A.; Tasarım ve Dizayn - S.A., H.Y., N.E., M.A.; Denetleme - S.A., H.Y., N.E., M.A.; Kaynaklar - S.A.; Malzemeler - S.A.; Veri Toplama ve/veya İşleme - S.A.; Analiz ve/veya Yorum - S.A.; Lite- ratür Taraması - S.A.; Yazıyı Yazan - S.A.; Eleştirel İnceleme - S.A.

\section{REFERENCES}

1. Marchand E, Cordier JF. Idiopathic chronic eosinophilic pneumonia. Orphanet J Rare Dis 2006; 1:11. [CrossRef]

2. Akuthota P, Weller PF. Eosinophilic pneumonias. Clin Microbiol Rev 2012; 25:649-60. [CrossRef]

3. Crowe M, Robinson D, Sagar M, Chen L, Ghamande S. Chronic eosinophilic pneumonia: clinical perspectives. Ther Clin Risk Manag 2019; 15:397-403. [CrossRef]

4. Pan $Y$, Guan $H$, Zhou S, Wang Y, Li Q, Zhu T, et al. Initial $\mathrm{CT}$ findings and temporal changes in patients with the novel coronavirus pneumonia (2019-nCoV): a study of 63 patients in Wuhan, China. Eur Radiol 2020; 30:3306-9. [CrossRef]

5. Ai T, Yang Z, Hou H, Zhan C, Chen C, Lv W, et al. Correlation of chest CT and RT-PCR testing in coronavirus disease 2019 (COVID-19) in China: a report of 1014 cases. Radiology 2020: 296:E32-E40. [CrossRef]

6. Infectious Diseases Society of America Guidelines on the Diagnosis of COVID-19, 5 Mayis 2020. https://www.idsociety.org/practice-guideline/covid-19guideline-diagnostics/.

7. Li T, Lu H, Zhang W. Clinical observation and management of COVID-19 patients. Emerg Microbes Infect 2020; 9:687-90. [CrossRef]

8. Tassinari D, Di Silverio Carulli C, Visciotti F, Petrucci R. Chronic eosinophilic pneumonia: a paediatric case. BMJ Case Rep 2013; 2013:bcr2013008888. [CrossRef]

9. Kim Y, Lee KS, Choi DC, Primack SL, Im JG. The spectrum of eosinophilic lung disease: radiologic findings. J Comput Assist Tomogr 1997; $21: 920-30$. [CrossRef]

10. Feng $H$, Liu $Y$, Lv M, Zhong J. A case report of COVID19 with false negative RT-PCR test: necessity of chest CT. Jpn J Radiol 2020; 38:409-10. [CrossRef]

11. Kanne JP. Chest CT findings in 2019 novel coronavirus (2019-nCoV) infections from Wuhan, China: key points for the radiologist. Radiology 2020; 295:16-7. [CrossRef]

12. Xie X, Zhong Z, Zhao W, Zheng C, Wang F, Liu J. Chest CT for typical coronavirus disease 2019 (COVID-19) pneumonia: relationship to negative RT-PCR testing. Radiology 2020; 296:E41-5. [CrossRef]

13. Guan $W, N i$, Hu Y, Liang WH, Ou CQ, He JX, et al. Clinical characteristics of coronavirus disease in China. N Engl J Med 2020; 382:1708-20. [CrossRef] 
14. Zhu Y, Liu YL, Li ZP, Kuang JY, Li XM, Yang YY, et al.

virus disease (COVID-19). J Infect 2020. [CrossRef] Clinical and CT imaging features of 2019 novel corona- 